\title{
Anthropological Portrait of a Home Turned Into a Tourist Resource
}

\author{
Helena Tolić \\ University of Zagreb, Faculty of Humanities and Social Sciences, Croatia \\ helenaogo8@gmail.com
}

This article presents a part of research conducted on Radunica, a street located in Split, Croatia. Its primary purpose is to present and name the processes that took place in the local community, specifically the connection and the dynamics of changes caused by the tourist activities of the locals. The goal is to show how emotional attachment to home and the usage of it as a resource for profit influences and changes everyday life in the community. Through open-ended interviews, participation, observation, and a phenomenological approach, I have found that tourist activities in Radunica, alongside the financial gain as the most beneficial effect of tourism, are significantly changing the everyday life and culture of the locals by altering the notion and emotional connection to one's home. In this manner, the sustainability of local communities becomes questionable, and collateral damage is also done to tourist activity. The main premise is that tourism is not a negative force that ruins communities, but that it can and should be designed and controlled, so it serves the local community and not vice versa. The goal of this article is not to present the positive or negative influences of tourism but to raise awareness about some deficiencies of tourist activities in local communities and to look in the direction of solutions.

Keywords: tourism, tourist activity, local community, Radunica, commodification, touristification

https://doi.org/10.26493/2335-4194.11.155-16o

\section{Introduction}

Since 2004, a small street named Radunica, located east of the city centre of Split, which is the largest city in the Dalmatia region of Croatia, has gradually become a very popular tourist destination. With every new tourist season, Radunica gains more features of a typical tourist settlement, which is causing many changes in the everyday life and culture of its inhabitants. The tourist activity is realised mainly through renovations of old Mediterranean stone houses and the process of turning them into suitable apartments for tourists, with charming Mediterranean detail. Before 2004, tourism and the presence of tourists in Radunica was rare and sporadic. Not many locals were renting their homes or parts of their homes to tourist until the extensive expansion of the tourist activity. Nowadays, most of the houses in Radunica are rental spaces, or at least one or more storeys inside houses are turned into apartments for tourists. Tourist activity has become a massive and significant part of the everyday lives of the local community.

The implications of these tourist activities of local inhabitants have been the subject of my ongoing research since 2013. Through the anthropological lens, I have been studying various materialisations and manifestations of tourism in the local community of Radunica for the previous five years. However, here I will be taking a closer look at the process and results of making one's home a tourist resource. My goal is contouring the main characteristics of the changes that 
took place in Radunica for the (roughly) last fifteen years.

The street of Radunica is known as a kaleta in Split; the word kala or kaleta in the dialect of the region of Dalmatia means a small and narrow street. Its primary and predominant characteristic is Mediterranean architecture, which implies ancient stone houses and gardens with Mediterranean vegetation. Radunica is the central street of the Lučac neighbourhood, which is one of the first neighbourhoods that were constructed outside of the historical city centre, Diocletian's Palace, which was built during the reign of the Roman Emperor Diocletian in the 4th century AD The earliest historical documents found about the Lučac neighbourhood date back to the 13th century AD (Kečkemet, 1986). Therefore, Mediterranean historical heritage alongside the geographical position of Split on the coast of the Adriatic Sea are the main characteristics and leitmotivs used in the development of Split as a tourist destination. ${ }^{2}$ Radunica with its convenient micro-location adjacent to the city centre, its old stone architectural heritage, and the entrepreneurial actions of its inhabitants quickly gained significant success within the tourist industry as a desirable location for self-catering apartment rental. The theoretical base for comprehension of the factors that contributed to changes that took place in the small local community of Radunica is the understanding of a city as a continual process (Low, 2006).

I grew up in Radunica, but with every new visit I realised that it was inevitably changing, and this process was defined and determined by the industry of tourism. At the beginning of my research, this realisation came as an obstacle, as I felt that tourism had invaded my home. It took some time to distance myself from that feeling. The process of balancing between myself as a child of my neighbourhood and myself as an anthropologist was challenging and an ongoing learning experience. I heard everything that was said, felt and understood it as one of the locals, while

${ }^{2}$ Not only Split used this strategy. In fact, Croatia's official slogan for the international tourism campaign for fifteen years used to be 'Croatia - the Mediterranean as it once was' until it was replaced with 'Croatia - full of life' in 2015.
I was simultaneously re-evaluating, rationalising, and translating everything found into an anthropological discourse. Thus, the theoretical framework of this research is installed in auto-cultural defamiliarisation, a process of estrangement from the personal (Gulin Zrnić, 2006). However, early on I decided not to make a dichotomy between the experience I had in Radunica as my home and Radunica as the field of my study, with the goal of not subordinating my work to the ostensible ideal of objectivity. Instead, I decided to balance between Geertz's (2010) 'experiences-near' and 'experiences-distant', shifting these terms back and forth in an attempt to understand Radunica as both a home and a research field. I have then looked at these new processes of change that were motivated by the tourist activity of the locals through the lens of the anthropology of space and place, or more precisely through the concept of social production and the social construction of space (Low, 2006b). The social production of space presented by Low includes social, economic, ideological, and technological factors that result in the creation of material surroundings. The social construction of space refers to the real transformation of space through social interactions, feelings, memories, usage of the space or conversations that project certain meanings (Low, 2006b). This perspective allowed me to focus on specific processes and changes in the notion of Radunica as a home and tourist settlement.

\section{Methodology}

To gather data, I used different methods of research. The first was an observation of social interactions between locals and participation in different jobs related to the rental of apartments to tourists. I also used the method of open-ended face-to-face and telephone interviews with various locals of Radunica who have connections to tourism. Since most of their activities in the first years of operating as tourist workers formed a part of the informal economy, I had many problems finding individuals who would be willing to talk to me. The mere fact that I was discovering locations and their connection with the informal economy made most of the locals unwilling to cooperate with me. 
In addition to these two methods, I used a phenomenological approach, researching through praxis, the physical senses, working as a host, and communicating with tourists, being in the street and in the tourist apartments, serving as a translator, an interior decorator of tourist apartments, photographer and a cleaning lady. I was basically doing everything I could as one of the local hosts. With the locals, I shared their private time, listening to the challenges they were dealing with as tourist hosts. The fact that I am from Radunica gave me an opportunity to use the location of my family home as an observing point for the interactions that took place in the street. I used my private memories as well as written notes before commencing with interviews and before researching the theoretical findings of other authors. Overall, this is a qualitative study immersed in the anthropology of space and place, auto-anthropology, and the anthropology of tourism.

\section{Touristification of Radunica}

Here, I will be describing interconnected factors that enabled the touristification of Radunica. Touristification is the process that transforms a place through the presence of many tourists and saturation with tourist facilities, which becomes visible through changes of the spatial, social, economic, and cultural characteristics of a place (Vojnović, 2016, p. 45).

The city of Split had a tradition of transit tourism in Yugoslavia, so in terms of private tourist accommodation, its potential was not fully developed by today's standards. In the early 2ooos, Croatia started to invest more in the development of tourism. This period was a post-war time in Croatia, and the beginning of a bad economic situation for many Croats who were losing their jobs or retired with small pensions that could not adequately support themselves. With the global economic crisis, tourism became an opportunity to solve financial difficulties in the years that followed. As Croatia was becoming more attractive to tourists, the lack of accommodation in Split became evident. Very quickly, the city was losing the label of a transit city and was becoming a popular tourist destination.

In 2004, the (mostly informal) tourist activity star- ted to gain power when the locals organised collaboration intra muros by dividing roles of hosts and gatherers ${ }^{3}$ between themselves. The first group owned apartments, and the later was going to the main bus station to find tourists that were looking for accommodation. Gatherers would walk with them back to Radunica, helping to carry their bags. The host would then pay the gatherer $30 \%$ of what he was making. Radunica started being used as a resource and was developed into a tourist product. Due to tourism demands, neighbourly relationships became monetised and ran by the logic of profit (Šurán, 2016). Radunica turned into a place of the collision of the formal and informal economies, ${ }^{4}$ a place of financial exchange, a place of creation of a tourist product and formation of new social-business relationships.

When asking about the motives and causes for participating in tourist activities, most of the answers I received from locals showed that renting to tourists was, in fact, a strategy of survival (Rubić, 2013). 'It was a pure necessity, for the love of God, only to survive,' said Bili summing up the motives of many other locals at the beginning of their tourist activities. However, the answer to the question about why somebody's home became a tourist resource is not that simple. The influence of the global industry of tourism, especially the demand of tourists to experience something new and different than their usual life was a crucial inducement that merged with the fact that, in the first decade of the 21st century, Croatia was a new player on the global level of the tourism industry.

Boissevain (2008, p. 26) explains the need for a tourist to experience something different and authentic, to learn about someone else's heritage, to observe

${ }^{3}$ In Croatian, they were called iznajmljivači and sakupljači in Radunica. Sakupljači or gatherers were also called 'the ones that look for tourists', 'the ones that go to the station', 'the ones who pick-up tourists'.

${ }^{4}$ The shift of the tourist activity from informal to (mostly) formal economy was a consequence of the frequent tourist inspections and sanctions of the authorities. The process of turning businesses legal became accelerated in 2007. As a consequence, in the years that followed, the role of gatherers stopped being a necessity and was replaced by advertising platforms, such as www.airbnb.com and www.booking.com. 
the Other from up close. For almost 15 years, Croatia was advertised as 'The Mediterranean as it once was', emphasising exactly the fact that it still was not exploited by the tourist industry nor overcrowded with tourists. Simultaneously, Croatia was reclaiming the undiscovered Mediterranean part of its identity as the right one (cf. Škrbić Alempijević, 2012). These factors influenced the locals of Radunica, making them aware that their home could have value in the tourist market. According to Simmel (1978, in Appadurai, 1986, p. 3), value is not an inherent property of objects; it is a judgment made about them by subjects. This creates space between the desire and enjoyment that is overcome through economic exchange (Simmel, 1978, in Appadurai, 1986). Under the influence of the global market, locals realised that their way of life, the location of their home, the Mediterranean heritage and architecture, their history and culture, in fact, are desirable merchandise that could improve their economic standard significantly. That was what occurred in 2003 and 2004 when a few locals started the process of turning their homes into tourist resources. Soon this praxis expanded to massive proportions. It all started with the hosts and the gatherers, and profit was the only criteria that made this transformation worthwhile to them. The awareness of desirability of these types of locations was quickly materialised in Radunica in two ways. First in the form of 'apartmanisation' and later through the aestheticisation of Radunica. Mrki, a local host, gives an example of apartmanisation, a phenomenon of saturating place with rental property for tourists:

Everything is rented out before it was just extra space, but now every single hovel, every garage, every basement, every possible business space, storage, stores, everything was reorganised and turned into a bedroom. [...] anything that they could, they turned into apartment and rooms. They throw in two or three beds, they build in a shower, put in a toilet and that is it.

The process of excessive apartmanisation is not over; the number of apartments is growing with every new season. During the low season, old stone houses are remodelled into new and attractive apartments. The imperative of attractiveness became important since there was more competition between the locals; once neighbours and friends, they became competitors in the tourist market. Apartmanisation was promptly followed by the process of the aestheticisation of Radunica. The main characteristic of aestheticisation was the 'Mediterraneanisation' of the place, that is, emphasising the idealised and easily recognisable Mediterranean symbols. Apartments and the street were purposely filled with motifs, such as bare stone walls, Mediterranean plants and herbs, photos of antiques, lavender in a vase, lemon trees, seashells on dining tables, old window treatments called grilje and škure were remodelled, flower pots put on stairs and windows, etc. The goal was to meet the expectations of the ideal Mediterranean place. In contrast, before apartmanisation, the goal of making their home beautiful was not carefully thought through; it was not analysed with the objective of being exhibited, judged, and admired by the Other. Before mass tourist activity, Radunica was not meant to be attractive. In fact, many villas and exclusive and remodelled apartments were somebody's homes just a few years ago. From the perspective of today's aesthetics, they were in poor condition with a patina of time visible on many walls. Still, the everyday life and interactions of locals in the common space were more vivid, intimate, and active than today. Locals utilised the space more often and freely to socialise; there were many more local businesses that were common spots for social interaction. Now, with profit in mind, the locals used and magnified Mediterranean symbols as an answer to the demands that came from the tourist industry. Mediterranean identity was used as a tool in the process of aestheticisation with the goal of attracting tourists: ${ }^{5}$

Spend a memorable, pleasant and romantic holiday in the heart of the old town, in the Stonehouse. Authentic accommodation, antique style. Feel the spirit of the Mediterranean! Go to the

\footnotetext{
${ }^{5}$ Example of advertising of a property in Radunica, see http://www.adriatic-home.com/Croatia/Split/Radunica/ Apartments-STONE-HOUSE-6120
} 
beach, visit the city's landmarks, visit the monuments, museums, galleries, concerts [...] taste the superb Mediterranean cuisine, relax, sleep [...] soak up the sun and the culture. Listen to the sound of the waves. Enjoy the beautiful Mediterranean climate, crystal clear sea and warm sands!

Combined, these actions resulted in the commodification of home, where once private and homey characteristics and particularities are turned into objects of trade. Tourists are invited to enter personal domains and share time and space with the local inhabitants. Tourists are seeking leisure, relaxation, and adventure while locals are looking for financial gain from a place they are emotionally attached to, trying to maintain everyday life in new circumstances. The fact that Radunica used to be (only) a home is extremely significant. The effects of the commodification of home are many, as Luči, one of the locals, explains:

Radunica definitely became a tourist settlement. Every house has a sign for a flat, apartment or some kind of hostel. The feeling is a little creepy. On a rare occasion I have a chance to say 'Hi' to someone I know, and sometimes I feel like I am in another city. Before [tourism] I felt better, definitely. I have nothing against the visitors from other countries, but now there are more foreigners than locals.

Everything is done for profit, and that changed good neighbourly relations a lot. I liked it better before. Radunica as a tourist settlement, I mean, that's not my home. [...] I mean it will always be my home. I still feel like I belong. I notice that everything is different, but it's still Radunica. I mean it is, and it isn't. When it comes to people, it isn't. For the most part, people have changed. All of that, that tourism, it created a distance between people. It is not as pleasant as before because the relationships are not like before.

As Luči observed, monetised relationships were a product of a rival culture that emerged as a side effect of non-planned tourist activity. Rivalry caused alienation between local inhabitants because their collab- orations were often unstable and depended on emotional connections. Changes in social relations and interactions were significant and altered everyday life and the habits and culture of locals. For example, the apartmanisation of Radunica caused the disappearance of crafts shops, stores, coffee bars, and other businesses in favour of self-catering apartments for rent. Prices of real estate have risen and are sold almost exclusively for rental purposes, so many people sold their property to move away from tourism, and not many young families are willing or capable of buying a home in these conditions. Just like tourism itself, life in Radunica became seasonal; crowded and loud in spring and summer, quiet and slow during winter and fall. Locals are making personal plans and arranging their lives around the tourist season. With the infrastructure of Radunica transformed, the way locals use space also changed: there are fewer places where people socialise, the street is arranged to look beautiful for the use of tourists, many houses are empty during low season, there are fewer common places since most of the patios and gardens are closed now with fences and hidden for the privacy of tourists. The locals experience Radunica in two overlapping dimensions: as a home and as a tourist settlement. The first one is slowly entering the realms of nostalgia, and its image is fading. Radunica as a tourist settlement is rapidly gaining more power every new tourist season.

\section{Conclusion}

All the processes described show that tourism acts as an agent of change (Šurán, 2016, p. 96). Although all the results speak in favour of this conclusion, it is important to realise that tourism is not something as uncontrollable as a force of nature. It can, in fact, be designed and controlled so that it serves the community. Although in the beginning tourism in Radunica was not planned and was informal, today almost all tourist activity forms part of the formal economy and is guided by tourist policies. Still, there seem to be little or no awareness of the possible adverse effects that tourism has on the local community. I do not see tourism as a destructive force per se, but I see significant gaps, oversights and negligence in how the politics of tourism in Croatia is mirrored in Radunica. 
There is no awareness of the importance of the local community and its culture; there are no actions that would adapt the tourist activities so that they serve the locals. In fact, quite the opposite is happening the local community serves the industry and is often depending on it. The result is the creation of a tourist settlement that is becoming detrimental to the conception of home. Paradoxically, precisely the way of life of the local communities is a pull factor for the tourists the attractive features of the ever-desirable authenticity. In this pace of touristification of Radunica, those features are slowly disappearing. So, by neglecting the local community, the damage is simultaneously done to the tourism of Radunica itself. What I mean is, if in some time from now tourists are getting only the experience of living in tourist settlement and not the experience of the life in a local Mediterranean community, it could easily become a push factor for the tourists and endanger the sustainability of tourism. Therefore, I find that it is necessary to find ways that will stop the negative trends in the local community and promote the positive aspects of tourism. Furthermore, the local inhabitants could have an advantage and priority to rent to tourists. This could be mandated by tourist regulatory frameworks and strategies. It could stop the trend of selling property at high prices for rental purposes only, which is the reason that many locals sell their homes and leave Radunica. Young people and families could get tax exemptions when buying a home in areas that are becoming tourist settlements while almost entirely disappearing as domestic neighbourhoods. In this way, Radunica could recover demographically. With more investigation, many more ways could be found that would benefit Croatian society and even enhance tourist offerings and promote sustainability for tourism and for the local community.

\section{References}

Appadurai, A. (1986). Introduction: Commodities and the policies of value. In A. Appadurai (Ed.), The social life of things: Commodities and cultural perspective (pp. 3-64). Cambridge, England: Cambridge University Press.

Boissevain, J. (2008). Some notes on tourism and the revitalisation of calendrical festivals in Europe. Journal of Mediterranean Studies, 18(1), 17-42.
Geertz, C. (2010). Lokalno znanje: Eseji iz interpretativne antropologije. Zagreb, Croatia: AGM.

Gulin Zrnić, V. (2006). Domaće, vlastito i osobno: Autokulturna defamilijarizacija. In J. Čapo Žmegač, V. Gulin Zrnić, \& G. Pavel Šantek (Eds.), Etnologija bliskoga: Poetika i politika suvremenih terenskih istraživanja (pp. 7397). Zagreb, Croatia: Naklada Jesenski i Turk.

Kečkemet, D. (1986, 3 February). Feljton gradske rubrike: Splitski predjeli 26; Težački Veli varoš. Slobodna Dalmacija, 8.

Low, S. (2006). Teorijsko promišljanje grada. In S. M. Low, \& V. Gulin Zrnić (Eds.), Promišljanje grada: Studije iz nove urbane antropologije (pp. 17-58). Zagreb, Croatia: Naklada Jesenski i Turk.

Low, S. (2006b). Smještanje kulture u prostor: Društvena proizvodnja i društveno oblikovanje prostora u Kostarici. In S. M. Low, \& V. Gulin Zrnić (Eds.), Promišljanje grada: Studije iz nove urbane antropologije (pp. 92-123). Zagreb, Croatia: Naklada Jesenski i Turk.

Rubić, T. (2013). 'Ja se snađem.' Neformalna ekonomija i formalna nezaposlenost u Hrvatskoj. In J. Čapo \& V. Gulin Zrnić (Eds.), Hrvatska svakodnevica: Etnografija vremena i prostora (pp. 31-65). Zagreb, Croatia: Institut za etnologiju i folkloristiku.

Simmel, G. (1978). The philosophy of money. London, England: Routledge \& Kegan Paul.

Škrbić Alempijević, N. (2012). Festivali i identiteti studija slučaja. In P. Bujas (Ed.), Grad kakav bi trebao biti: Etnološki i kulturnoantropološki osvrti na festival (pp. 97184). Zagreb, Croatia: Naklada Jesenski i Turk.

Šurán, F. (2016). Turizam i teritorij: Uvod u antropologiju turizma. Pula, Croatia: Sveučilište Juraja Dobrile.

Vojnović, N. (2016). Utjecaj turistifikacije na fizionomska obilježja krajobraza unutrašnje Istre. Ekonomska- $i$ ekohistorija: časopis za gospodarsku povijest i povijest okoliša, 12(1), 44-57.

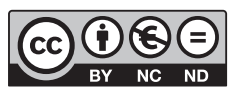

This paper is published under the terms of the Attribution- NonCommercial-NoDerivatives 4.0 International (CC B Y-NC-ND 4.0) License. 